\title{
Pathogenesis of oedema in protein-energy malnutrition: the significance of plasma colloid osmotic pressure
}

\author{
By MARTA FIOROTTO AND W. A. COWARD \\ MRC Dunn Nutrition Unit, Dunn Nutritional Laboratory, University of Cambridge \\ and Medical Research Council, Milton Road, Cambridge CB4 IXJ
}

(Received 16 October $1978-$ Accepted 22 January 1979) I. Rats were made oedematous by feeding them low-protein diets (protein:energy (P:E) 0.005$)$ ad lib.,
and measurements were made of plasma and interstitial fluid colloid osmotic pressures $\left(\pi_{p}\right.$ and $\pi_{i}$ respectively)
and interstitial fluid hydrostatic pressure $\left(P_{i}\right)$ before, and at the onset of, oedema formation. Taken together
as $\left(\pi_{p}-\pi_{i}+P_{i}\right)$ these forces oppose capillary pressure $\left(P_{c}\right)$ and thus determine rates of transcapillary
water filtration. Interstitial fluid was sampled, in non-oedematous and oedematous animals, from
perforated capsules implanted subcutaneously for the measurement of $P_{i}$. Blood, plasma and interstitial
fluid volumes were also determined.

2. In Expt I comparisons were made between animals fed on a control diet (P:E 0.210) and the lowprotein diet. In normal animals the ratio $\pi_{j}: \pi_{i}$ was approximately 2 , but in protein deficiency it was increased since reductions in the absolute value of $\pi_{i}$ matched those in $\pi_{p}$. These changes were observed 2 weeks after the start of the experiment and became more exaggerated when oedema appeared (weeks i 8-22).

3. $P_{i}$ was normally negative with respect to atmospheric pressure but increased to values close to zero when oedema formation occurred.

4. Despite the reductions in $\pi_{p}$ that were seen in the protein-deficient animals the sum of the forces opposing filtration $\left(\pi_{p}-\pi_{i}+P_{i}\right)$ did not change significantly during the experiment.

5. Plasma and interstitial fluid volumes expressed per $\mathrm{kg}$ body-weight (measured using ${ }^{125} \mathrm{I}$-albumin and ${ }^{35} \mathrm{SO}_{4}{ }^{2-}$ ) were unchanged as $\pi_{p}$ initially decreased in the protein-deficient animals but increased markedly with the onset of oedema.

6. In Expt 2 comparisons were made between animals fed the low-protein diet ad lib. and others fed on the control diet in restricted amounts so that weight loss was the same in the two groups of animals.

7. The wasting induced by restriction of the control diet did not produce reductions in $\pi_{p}$ or $\pi_{i}$ and values for $P_{i}$ were normal. Changes in the animals fed on the low-protein diet were similar to those observed in Expt I. By using ${ }^{51} \mathrm{Cr}$-labelled erythrocytes it was shown that the expansion in plasma volume that occurred when oedema appeared in the protein-deficient animals was mainly due to a reduction in total erythrocyte volume. Blood volume did not increase significantly.

8. It was concluded that in the hypoproteinaemia induced in the experimental animals reductions in the value of $\pi_{p}$, which might otherwise result in an imbalance of forces that would produce excessive rates of transcapillary water filtration, were compensated for by reductions in $\pi_{i}$. Increases in $\boldsymbol{P}_{i}$ also compensated but were quantitatively less important.

9. The significance of the results is discussed in terms of the pathogenesis of oedema in kwashiorkor and the concept of an oncotic threshold for oedema formation in hypoproteinaemia.

Oedema in kwashiorkor specifically distinguishes this disease from other forms of proteinenergy malnutrition (Lancet, 1970) but there is no general agreement as to its cause. The early discovery that plasma protein concentrations were low, and that albumin:globulin ratios were reduced, in children with kwashiorkor (findings of Harvey, and of Cofino Ubico \& Klée, cited by Trowell et al. 1954a) was recognized by contemporary workers as being significant so that Trowell et al. (1954b) were able to state that 'the low level of serum albumin found in children in the acute stage of kwashiorkor plays a considerable part in the production of oedema'. It was presumably thought that oedema formation could be explained in terms of Starling's hypothesis of transcapillary fluid dynamics (Starling, I896) which is now usually written as:

$$
J=K_{f}\left(\left(P_{c}-\sigma \pi_{p}\right)-\left(P_{i}-\sigma \pi_{i}\right)\right)
$$

0007-I 145/79/3236-220I \$01.00 (C) 1979 The Nutrition Society 
where $J$ is the net capillary filtration rate, $P_{c}$ is the capillary hydrostatic pressure, $P_{i}$ is the interstitial fluid hydrostatic pressure, $\pi_{p}$ is the plasma colloid osmotic pressure, $\pi_{i}$ is the interstitial fluid colloid osmotic pressure, $K_{f}$ is the capillary filtration coefficient, and $\sigma$ is the reflexion coefficient.

Discounting the influence of other quantities in the equation, this hypothesis indicates that in hypoproteinaemia reductions in $\pi_{p}$ should result in excessive water filtration out of the capillaries and a progressive accumulation of interstitial fluid. However, it is well known that in normal individuals interstitial fluid volume is held fairly constant despite the fact that any small variations in $P_{c}$ or $\pi_{p}$, for example, might be expected to produce changes in volume. Furthermore, Coward (1975) showed that an oncotic threshold for oedema formation could be described in children 'at risk' to oedematous malnutrition; such thresholds also occur in other instances where oedema appears in hypoproteinaemia (Schultze \& Heremans, 1966a) and many workers have noted that plasma protein concentrations in individual cases of kwashiorkor do not correlate particularly well with the extent of oedema observed clinically (Jelliffe et al. I954; Waterlow et al. I960; Montgomery, 1963; Srikantia, I968; Waterlow \& Alleyne, 1971; Klahr \& Alleyne, 1973; Golden et al. 1975). Thus it is difficult to reconcile simple interpretations of Starling's relationship to accepted clinical observations and for these reasons other explanations for oedema formation in kwashiorkor have been put forward.

The most consistently advocated idea has been that mechanisms concerned with the retention of sodium and water are factors that precipitate the appearance of oedema (for a review, see Klahr \& Alleyne, 1973). It is likely that $\mathrm{Na}$ and water retention is a physiological event that occurs to meet the situation of oedema formation since, if attempts are made to maintain the chemical and physical constancy of the internal environment retention of $\mathrm{Na}$ and water must occur when oedema is forming, but this does not necessarily mean that a state in which oedema formation occurs can be attributed to $\mathrm{Na}$ and water retention per se.

It seems therefore, that there are as yet no completely adequate explanations for the development of oedema in kwashiorkor. For this reason the present experiments were designed to investigate some of the factors that, in the long term, control the distribution of extracellular fluid between the plasma and interstitial fluid in the development of nutritionally-induced hypoproteinaemic oedema. Specifically, $\pi_{p}, \pi_{i}$ and $P_{i}$ were measured in rats fed on low-protein diets. It was thought that the values for $\pi_{p}-\pi_{i}+P_{i}$, the sum of forces opposing filtration, assuming $\sigma$ is approximately I (see Taylor et al. I973), could be crucial in relation to oedema formation. In some animals measurements were also made of plasma volume, blood volume and interstitial fluid volume in order to monitor changes in the distribution of extracellular fluid volume.

\section{EXPER IMENTAL}

Animals and diets

Male hooded rats from a specific pathogen-free colony were used in the experiments. They were raised in groups of eight per litter and weaned when they were 3 weeks old. The diets subsequently fed were the control or low-protein diets described by Coward et al. (I977) with P:E values of 0.210 (control diet; C), 0.032 (low-protein diet; LP) or 0.005 (very-lowprotein diet; VLP). All animals received diet C for at least I week after weaning.

\section{Experimental procedures}

Interstitial fluid pressure. Perforated capsules (external dimensions, $29 \times 14$ or $24 \times 8 \mathrm{~mm}$; wall thickness, $1 \mathrm{~mm}$; hole diameter, I $\mathrm{mm}$; hole-density, $20 / \mathrm{cm}^{2}$ ) were made from the 
polyacetal, Delrin (Du Pont de Nemours International - SA Geneva, Switzerland) and implanted into the subcutaneous space of the abdomen through a dorso-lateral incision. Capsules of this type subsequently become lined internally with tissue which surrounds a fluid-filled space. Interstitial fluid pressure was measured by introducing a $2 \mathrm{I}$-gauge needle through the skin into the fluid reservoir of the capsule. The needle was connected by a length of Teflon tubing (I.I9 mm internal diameter) to a pressure transducer (SE 4-88; SE Laboratories Ltd, Feltham, Middx) which was linked through a venous pressure module (SEM 425; SE Laboratories Ltd) to a potentiometric recorder giving a full-scale pen response for $100 \mathrm{~mm} \mathrm{H}_{2} \mathrm{O}$ pressure change. The zero pressure reference point was taken at the mid-point of the capsule and all pressure readings were made with the animal supine under light diethyl ether anaethesia. Evidence validating the capsule technique for measuring interstitial fluid pressure has been reviewed by Guyton et al. (197I).

Colloid osmotic pressure. Colloid osmotic pressures of interstitial fluid (sampled from capsules) and plasma, stored at $-20^{\circ}$ before analysis, were determined using $70 \mu \mathrm{l}$ sample in a Knauer Membrane Osmometer (type MOM; Dr H. Knauer, I Berlin-37 Zehlendorf, Holstweg I8, Germany). Measurements were made at $37^{\circ}$ using a Ringer solution (g/1 8.0; sodium chloride, 0.2 potassium chloride, 0.2 calcium chloride, $\mathrm{I} \cdot 0$ sodium bicarbonate) as the permeating solution; the cellulose acetate membranes used were impermeable to substances of molecular weight greater than Ioooo.

Blood, plasma and interstitial fluid volumes. When plasma and interstitial fluid volumes were measured simultaneously the rats were anaesthetized by intraperitoneal injection of $60 \mathrm{mg}$ pentobarbitone sodium $/ \mathrm{kg}$ body-weight. The kidneys were ligatured and approximately $3 \mu \mathrm{Ci}^{35} \mathrm{SO}_{4}{ }^{2-}$ (The Radiochemical Centre, Amersham, Bucks) in $20 \mu \mathrm{l}$ physiological saline $(9 \mathrm{~g} \mathrm{NaCl} / \mathrm{l})$ containing sulphate $(2 \mathrm{mM})$ were injected into the right femoral vein. After $40-45 \mathrm{~min}$ approximately $0.05 \mu \mathrm{Cj}$ human ${ }^{125} \mathrm{I}$-albumin (The Radiochemical Centre) were injected into the left femoral vein and 3-4 min later a blood sample was collected into a heparinized syringe by cardiac puncture. The intervals required for the equilibration of the injected isotopes were based on values obtained by Katz et al. (1970).

When ${ }^{51} \mathrm{Cr}$-labelled erythrocytes were used to determine blood volume the labelled cells were prepared using a modification of the technique described by Bratteby (1967). Approximately I. $5 \mu \mathrm{Ci}{ }^{51} \mathrm{Cr}$ (The Radiochemical Centre) in $100 \mu \mathrm{l}$ of a suspension of cells in Eagle's solution were injected into a femoral vein and a heparinized blood sample was obtained by cardiac puncture 5 min later.

${ }^{125} \mathrm{I}$ and ${ }^{51} \mathrm{Cr}$ activity was measured in a gamma-radiation counter (SC-722, Dual ScalerSpectrometer; ICN Pharmaceuticals NV, Instruments Division, Mechelen, Belgium) and ${ }^{35} \mathrm{~S}$ estimated using a liquid scintillation counter (Model 2425, Tri-carb liquid scintillation spectrometer; Packard Instruments Ltd, Caversham, Berks) with appropriate corrections for quenching and ${ }^{125} \mathrm{I}$ counts in the sample; all activities were measured to an accuracy of $\pm \mathrm{I} \%$. Blood, plasma and extracellular fluid volumes were calculated from the general relationship:

$$
\text { volume }(\mathrm{ml})=\frac{\text { counts } / \mathrm{min} \text { injected }}{\text { counts } / \mathrm{min} \text { per } \mathrm{ml} \text { plasma or blood. }}
$$

Interstitial fluid volume was estimated as (extracellular fluid volume)-(plasma volume). When plasma volume was calculated from blood volume, measurements of packed cell volume were made using a Coulter Counter Model $Z_{\mathrm{B} 1}$ equipped with appropriate computer units (Coulter Electronics Ltd, Harpenden, Herts).

\section{Experimental design}

Two series of experiments were performed. In the first (Expt I) capsules were implanted I week after weaning and during a 3-week period allowed for the capsules to become 
established the animals continued to receive diet $\mathrm{C}$. At the end of this period thirty-two animals were allocated to groups receiving diet $\mathrm{C}$ and the same number to those fed on diet VLP; at this stage a further eight animals were subjected to the experimental procedures. In this series of experiments measurements were made of plasma volume (using ${ }^{125}$ I-albumin), interstitial fluid volume, interstitial fluid pressure $\left(P_{i}\right)$ and plasma and interstitial fluid colloid osmotic pressure $\left(\pi_{p}\right.$ and $\pi_{i}$ ). When all the procedures were carried out interstitial fluid pressure was first measured and then samples of fluid aspirated from the capsule. After this the fluid volumes were estimated and the final blood sample taken provided plasma for the measurement of $\pi_{p}$. In addition to the measurements made at the start of the experimental period (week o) measurements were also made at weeks 2,5 and 9.5 (diet VLP only) thereafter, and when the animals fed on diet VLP developed oedema (weeks 18-22).

The second series of experiments (Expt 2) was carried out to provide further information on changes during the development of oedema in rats fed on diet VLP and to investigate the effect of wasting. With experience gained from Expt I some alterations were made to the general experimental design. Capsules were again implanted when the animals were 4 weeks old but at this stage they were all transferred to diet LP so that complete recovery from the implantation of the capsules could occur without the animals becoming too large; it was hoped that this manoeuvre would allow a more rapid development of oedema when they were fed on diet VLP. In addition, to confirm that large increases in plasma volume occurred in oedematous animals (a finding in Expt 1 ) ${ }^{51} \mathrm{Cr}$-labelled erythrocytes were used rather than ${ }^{125}$ I-albumin and plasma volumes were calculated from this measurement of blood volume, and packed cell volume. Viart (1977) has recently suggested that the distribution space for labelled proteins may change in malnutrition. No measurements were made of interstitial fluid volume.

The animals were fed on diet LP until they were 10 weeks old and then twenty-two were fed on diet VLP ad lib. and twenty-two were fed on diet $\mathrm{C}$ in restricted amounts that produced the same rate of weight loss as that occurring in the animals fed on diet VLP. Measurements were made on a further eight animals at the start of the experimental period (week 0 ) and on the experimental animals is and I 7 weeks later.

\section{RESULTS}

In general the animals tolerated the presence of the capsules well but two problems did arise. In the later stages of the experimental period the capsules in some animals fed on diet $\mathrm{C}$ ad lib. became completely occluded by tissue; in rats receiving diet VLP or diet $\mathrm{C}$ in restricted amounts there was no tendency for this to occur but because of the animals' wasted condition the capsules sometimes became exposed and had to be removed. Because of these difficulties, it was not always possible to obtain a complete set of pressure measurements. In addition some animals fed on diet VLP, or diet C in restricted amounts, failed to survive either the diethyl ether or sodium pentobarbitone anaesthesia; individual values for $\pi_{p}, \pi_{i}$ and $P_{i}$ were therefore used in calculating group means for the pressure values (Fig. I and Tables I and 3) only when a complete set of pressure measurements was available. The results for blood and plasma, and interstitial fluid volumes (Tables 2 and 4) did, however, include some animals from which it was not possible to obtain all the pressure measurements.

\section{Expt I}

The animals fed on diet VLP gradually lost weight and after I 8 weeks had lost, on average, $34 \%$ of their original mean weight ( $177 \mathrm{~g}$ ). At this stage oedema began to appear but the 
Table I. Values $\left(\mathrm{mm} \mathrm{H}_{2} \mathrm{O}\right)$ for colloid osmotic pressures of plasma $\left(\pi_{p}\right)$ and interstitial fluid $\left(\pi_{i}\right)$, their ratio $\left(\pi_{p}: \pi_{i}\right)$, interstitial fluid pressure $\left(P_{i}\right)$ and the sum of forces opposing filtration $\left(\pi_{p}-\pi_{i}+P_{i}\right)$ in rats fed on diet $C$ (protein:energy $\left.(P: E) 0 \cdot 2 \mathrm{IO}\right)$ ad lib. or diet VLP $(P: E 0.005)$ ad lib.

(Values are means with their standard errors. Student's $t$ test was used in the analyses)

\begin{tabular}{|c|c|c|c|c|c|c|c|c|c|c|c|c|}
\hline \multirow{2}{*}{$\begin{array}{c}\text { Period } \\
\text { of } \\
\text { experiment } \\
\text { (weeks) }\end{array}$} & \multirow[b]{2}{*}{ Diet } & \multirow{2}{*}{$\begin{array}{l}\text { No. of } \\
\text { animals }\end{array}$} & \multicolumn{2}{|c|}{$\pi_{p}$} & \multicolumn{2}{|c|}{$n_{i}$} & \multicolumn{2}{|c|}{$P_{i}$} & \multicolumn{2}{|c|}{$\pi_{p}: \pi_{i}$} & \multicolumn{2}{|c|}{$\pi_{p}-\underbrace{}_{i}+P_{i}$} \\
\hline & & & Mean & SE & Mean & SE & Mean & $\mathrm{SE}$ & Mean & SE & Mean & SE \\
\hline 0 & C & 7 & 255 & 4 & 143 & 5 & -13 & 2 & $1 \cdot 8$ & 0.1 & 101 & 5 \\
\hline 2 & $\mathrm{C}$ & 7 & 270 & 5 & 138 & 6 & -15 & 2 & 2.0 & $0 . I$ & II 9 & II \\
\hline 2 & VLP & 8 & 203 & $6_{+t^{+}}^{* * *}$ & 70 & $4+* *$ & -26 & $I_{++1}^{* * *}$ & 3.0 & $0.2_{+\neq *}^{* * *}$ & 107 & 7 \\
\hline 5 & C & 8 & $27 I$ & 8 & I 36 & 4 & -32 & $3^{* *}$ & 2.0 & $0 . I$ & 102 & I I \\
\hline 5 & VLP & 8 & 192 & $3 * * *+$ & 64 & $7_{+\dagger+}^{* * * *}$ & -33 & $4^{* * *}$ & $3 \cdot 2$ & $0.3_{t \dagger}^{* * *}$ & 95 & 7 \\
\hline $9 \cdot 5$ & VLP & 6 & 181 & $3^{4 * *}$ & 48 & $I^{* 10}$ & -22 & $I^{* * *}$ & 3.8 & $0.1^{* * *}$ & 112 & 3 \\
\hline $18-20$ & C & 6 & 283 & $10^{*}$ & 139 & 8 & -30 & $5^{* * *}$ & $2 \cdot 1$ & $0 . I^{*}$ & II 5 & 9 \\
\hline $18-20$ & VLP & $3 t$ & 119 & $5_{\uparrow+t}^{* * *}$ & 13 & $3_{+\dagger+}^{* * *}$ & -1 & $1_{\varphi+\dagger}^{* * * *}$ & $9 \cdot 8$ & $I \cdot 8_{t+\dagger}^{* * * *}$ & IOI & I \\
\hline
\end{tabular}

Values significantly different from those at week $0:{ }^{*} P<0.05 ;^{* *} P<0.01,{ }^{* * *} P<0.001$.

Values for groups fed on diet VLP significantly different from corresponding groups fed on diet $C$; $\dagger P<0.05,+\dagger P<0.01,+\dagger \dagger P<0.001$.

$\ddagger$ Denotes oedematous animals.

time at which this was first observed varied from animal to animal. Oedema fluid accumulated in the subcutaneous tissues around the neck, cheek and fore-limbs but although all the animals had ceased to lose weight at this time the onset of detectable oedema was not marked by substantial weight gains; there were no spontaneous deaths in these animals.

Colloid osmotic pressures $\left(\pi_{p}\right.$ and $\pi_{i}$ ). Table I and Fig. I show the changes in $\pi_{p}$ and $\pi_{i}$ that occurred during the development of hypoproteinaemia. Although they were similar in absolute terms, reductions in $\pi_{p}$ and $\pi_{i}$ were proportionally different; alterations in $\pi_{i}$ were relatively greater than those in $\pi_{p}$ so that the $\pi_{p}: \pi_{i}$ ratio increased when $\pi_{p}$ was reduced (Table I).

Interstitial fluid pressure $\left(P_{i}\right)$. Changes in $P_{i}$ during the experiment are shown in Table $I$. In the first 5 weeks of the experiment $P_{i}$ decreased in both the control rats and those fed on diet VLP although the changes in the latter animals occurred more rapidly. After this time values for $P_{i}$ remained constant in the control animals but in the animals fed on diet VLP, in which both $\pi_{p}$ and $\pi_{i}$ were decreasing, $P_{i}$ became less negative so that when oedema developed $P_{i}$ was close to zero.

Forces opposing filtration $\left(\pi_{p}-\pi_{i}+P_{i}\right)$. Despite the different ways in which $\pi_{p}, \pi_{i}$ and $P_{i}$ changed throughout the experiment the sum of the forces opposing filtration (Table 1 ) were never significantly different from initial values in either group of animals nor were there significant differences between groups at any of the stages at which measurements were made.

Plasma and interstitial fluid volumes. In the control animals both plasma and interstitial fluid volumes ( $/ \mathrm{kg}$ body-weight) fell with age (Table 2 ). In the animals fed on diet VLP plasma volumes were always greater than those found in the control animals but were only increased significantly compared with values at week o, at weeks 18-22. Interstitial fluid volumes followed the same pattern of change during the experiment in both groups of animals except at weeks $18-22$ when oedema developed in the animals fed on diet VLP, and interstitial fluid volume increased. 


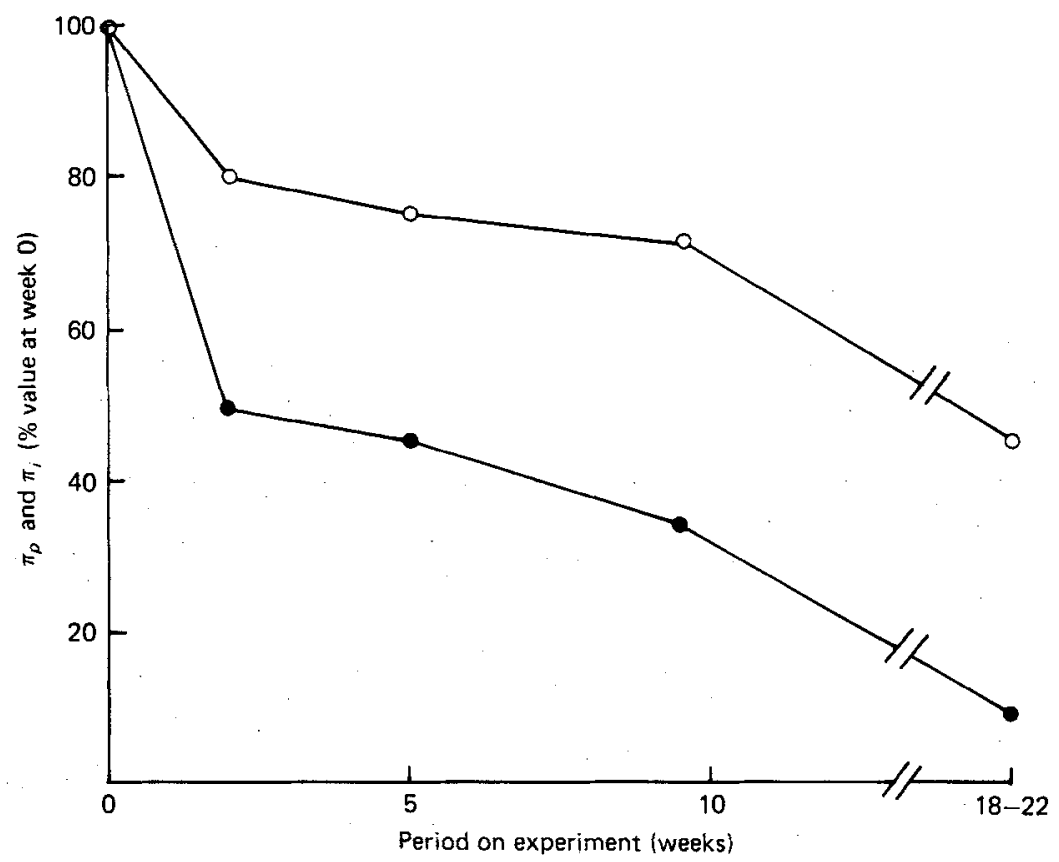

Fig. I. Plasma colloid osmotic pressure $\left(\pi_{p}\right)(O-O)$ and interstitial fluid colloid osmotic pressure $\left(\pi_{i}\right)(-)$ ), expressed as \% values at week $o$, in rats fed on diet VLP (protein:energy (P:E) 0.005) ad lib.

Table 2. Plasma and interstitial fluid volumes $(\mathrm{ml} / \mathrm{kg})$ in rats fed on diet $C$ (protein:energy $(P: E) 0.210)$ ad lib. or diet VLP $(P: E 0.005)$ ad lib.

(Values are means with their standard errors. Student's $t$ test was used in the analyses)

\begin{tabular}{|c|c|c|c|c|c|c|}
\hline \multirow{2}{*}{$\begin{array}{l}\text { Period of } \\
\text { experiment } \\
\text { (weeks) }\end{array}$} & \multirow[b]{2}{*}{ Diet } & \multirow{2}{*}{$\begin{array}{l}\text { No. of } \\
\text { animals }\end{array}$} & \multicolumn{2}{|c|}{ Plasma volume } & \multicolumn{2}{|c|}{ Interstitial fluid volume } \\
\hline & & & Mean & SE & Mean & SE \\
\hline 0 & C & 7 & $34 \cdot 9$ & $2 \cdot 0$ & 356 & 35 \\
\hline 2 & C & 7 & $30 \cdot I$ & $I \cdot 4$ & 288 & IO \\
\hline 2 & VLP & 8 & $33 \cdot 3$ & $1 \cdot 5$ & 309 & 17 \\
\hline 5 & C & 8 & $28 \cdot 3$ & $1 \cdot 5^{* *}$ & 273 & $8^{*}$ \\
\hline 5 & VLP & 8 & $36 \cdot 6$ & $I \cdot 5^{t+\phi}$ & 273 & $10^{*}$ \\
\hline $9 \cdot 5$ & VLP & 6 & $35 \cdot 8$ & $I \cdot I$ & 278 & 8 \\
\hline $18-22$ & C & 6 & 24.5 & $I \cdot 2^{* *}$ & 260 & 27 \\
\hline $18-22$ & VLP & $7 \ddagger$ & $6 \mathrm{I} \cdot \mathrm{I}$ & $2 \cdot 3+3 * t+$ & 457 & $60^{4}$ \\
\hline
\end{tabular}

Values significantly different from those at week $0: * P<0.05,{ }^{* *} P<0.01, * * * P<0.001$.

Values for groups fed on diet VLP significantly different from corresponding groups fed on diet $C$ : $\dagger P<0.05, \dagger+P<0.01,+\dagger+P<0.001$.

$\ddagger$ Denotes oedematous animals.

\section{Expt 2}

In this experiment the animals were introduced to the C and VLP diets after an initial period of feeding diet LP. This diet provides sufficient protein for weight maintenance but does not allow growth so that at the start of the experimental period the mean weight of the rats was $105 \mathrm{~g}$. After only I I weeks on the diets, five of the animals fed on diet VLP developed oedema and these were killed for analysis together with six non-oedematous animals from the same dietary groups and eleven from those receiving restricted amounts of 
Table 3. Values $\left(\mathrm{mm} \mathrm{H}_{2} \mathrm{O}\right)$ for colloid osmotic pressures of plasma $\left(\pi_{p}\right)$ and interstitial fluid $\left(\pi_{i}\right)$, their ratio $\left(\pi_{p}: \pi_{i}\right)$, interstitial fluid pressure $\left(P_{i}\right)$ and the sum of pressures opposing filtration $\left(\pi_{p}-\pi_{i}+P_{i}\right)$ in rats fed on restricted amounts of diet $C$ (protein: energy $\left.(P: E) 0.210\right)$ or diet VLP $(P: E 0.005)$ ad lib.

(Values are means with their standard errors. Student's $t$ test was used in the analyses)

\begin{tabular}{|c|c|c|c|c|c|c|c|c|c|c|c|c|}
\hline \multirow{2}{*}{$\begin{array}{l}\text { Period of } \\
\text { experiment } \\
\text { (weeks) }\end{array}$} & \multirow[b]{2}{*}{ Diet } & \multirow{2}{*}{$\begin{array}{l}\text { No. of } \\
\text { Animals }\end{array}$} & \multicolumn{2}{|c|}{$\pi_{p}$} & \multicolumn{2}{|c|}{$\pi_{i}$} & \multicolumn{2}{|c|}{$P_{i}$} & \multicolumn{2}{|c|}{$\underbrace{\pi_{p}: \pi_{i}}$} & \multicolumn{2}{|c|}{$\pi_{\mathcal{p}}-\pi_{i}+P_{i}$} \\
\hline & & & Mean & $\mathrm{SE}$ & Mean & $\mathrm{SE}$ & Mean & $\mathrm{SE}$ & Mean & $\mathrm{SE}$ & Mean & SE \\
\hline 0 & C & 8 & 225 & 10 & 96 & 5 & -28 & 4 & $2 \cdot 4$ & 0.2 & 101 & i \\
\hline I I & C & 6 & 239 & 9 & 126 & $\mathrm{II}^{*}$ & $-2 I$ & 2 & $2 \cdot 0$ & 0.2 & 92 & 10 \\
\hline II & VLP & $3 \ddagger$ & 131 & $13_{t+t}^{* * *+}$ & 33 & $12_{f+t}^{* * *}$ & -6 & $3 * *+$ & $5 \cdot 1$ & $1 \cdot 6_{t}^{*}$ & 92 & 9 \\
\hline & & 14 & 148 & & 48 & $8_{t+t}^{* * *}$ & -13 & 4 & 3.4 & $0.5 t$ & 88 & 0 \\
\hline 17 & C & 4 & 248 & 8 & 94 & 8 & -24 & 3 & $2 \cdot 7$ & 0.4 & I 32 & 14 \\
\hline 17 & VLP & $6 \ddagger$ & 124 & $4_{\dagger+t}^{* * *}$ & I4 & $\mathbf{2}_{t+t}^{* * * *}$ & -5 & $4 * * *$ & $9 \cdot 7$ & $x \cdot 4+\frac{* * *}{* *}$ & 105 & 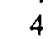 \\
\hline
\end{tabular}

Values significantly different from those at week $0:{ }^{*} P<0.05,{ }^{* *} P<0.01,{ }^{* * *} P<0.001$.

Values for groups fed on diet VLP significantly different from corresponding groups fed on diet $C$ : $\dagger P<0.05,+\dagger P<0.01,+\dagger \dagger P<0.001$.

$\ddagger$ Denotes oedematous animals.

Table 4. Blood, plasma and total erythrocyte volumes $(\mathrm{ml} / \mathrm{kg})$ in rats fed on restricted amounts of diet $C$ (protein:energy $(P: E) 0.210)$ or diet VLP $(P: E 0.005)$ ad lib.

(Values are means with their standard errors. Student's $t$ test was used in the analyses)

\begin{tabular}{|c|c|c|c|c|c|c|c|c|}
\hline \multirow{2}{*}{$\begin{array}{l}\text { Period of } \\
\text { experiment } \\
\text { (weeks) }\end{array}$} & \multirow[b]{2}{*}{ Diet } & \multirow{2}{*}{$\begin{array}{l}\text { No. of } \\
\text { animals }\end{array}$} & \multicolumn{2}{|c|}{ Blood volume } & \multicolumn{2}{|c|}{ Plasma volume } & \multicolumn{2}{|c|}{$\begin{array}{c}\text { Total erythrocyte } \\
\text { volume }\end{array}$} \\
\hline & & & Mean & SE & Mean & $S E$ & Mean & SE \\
\hline 0 & $\mathrm{C}$ & 8 & 63.0 & $1 \cdot 2$ & $39 \cdot 7$ & 0.7 & $23 \cdot 3$ & $I \cdot 0$ \\
\hline I I & $\mathrm{C}$ & 7 & $60 \cdot 9$ & $3 \cdot 3$ & $37 \cdot I$ & I. 4 & 23.8 & $2 \cdot 2$ \\
\hline I 1 & VLP & $\left\{\begin{array}{l}5 * \\
5\end{array}\right.$ & $\begin{array}{l}67.6 \\
50.6\end{array}$ & $4 \cdot I$ & $49 \cdot 0$ & $3.4^{* *+}$ & 18.6 & $1 \cdot 0$ \\
\hline 17 & C & 6 & $\begin{array}{l}59.0 \\
60.9\end{array}$ & $\begin{array}{l}1 \cdot 5 \\
2 \cdot I\end{array}$ & $\begin{array}{l}42.0 \\
33 \cdot 6\end{array}$ & $2 \cdot 1 *$ & $\begin{array}{l}17 \cdot 5 \\
27 \cdot 3\end{array}$ & $\begin{array}{l}0.4 t \\
1.6^{*}\end{array}$ \\
\hline 17 & VLP & $7 \ddagger$ & $66 \cdot 3^{t}$ & $I \cdot 4$ & $51 \cdot 0$ & $I \cdot 8_{t+\dagger}^{* t *}$ & $15 \cdot 3$ & $1 \cdot 7_{+++}^{* *}$ \\
\hline
\end{tabular}

Values significantly different from those at week $0: * P<0.05,{ }^{*} P<0.01,{ }^{* * *} P<0.001$.

Values for groups fed on diit VLP significantly different from corresponding groups fed on diet $C$ : $\dagger P<0.05$, $+\dagger P<0.01$, $+\dagger \dagger P<0.00$ r.

$\ddagger$ Denotes oedematous animals.

diet C. At 17 weeks the remainder of the rats fed on diet VLP developed oedema and at this stage the experiment was terminated and all the animals killed. Changes in oncotic and hydrostatic pressures throughout the experiment are shown in Table 3 . In general values for the animals fed on diet VLP changed as they did in Expt $I$ in that the sum of forces opposing filtration $\left(\pi_{p}-\pi_{i}+P_{i}\right)$ remained relatively stable despite reductions in $\pi_{p}$. Table 4 indicates that the increases in plasma volume that occurred in the oedematous animals were mainly a result of reductions in total erythrocyte volume; however, the increases observed in this experiment were less than those found in Expt 1 . These differences need further investigation, but it has been suggested that in malnutrition plasma volumes measured by ${ }^{125}$ I-albumin dilution are anomalously high (Viart, I977).

The wasted animals fed on restricted amounts of diet $C$ did not become hypoproteinaemic 
and in respect of measurement made in the experiments did not differ from the control animals in Expt $\mathrm{r}$.

\section{DISCUSSION}

\section{Factors preventing oedema formation in protein-deficiency}

The balance of the forces determining the net rate of water filtration $(J)$ out of the capillaries is described by the relationship previously defined: $J=K_{f}\left(\left(P_{c}-\sigma \pi_{p}\right)-\left(P_{t}-\sigma \pi_{i}\right)\right)$. In the present experiments gradual reductions in plasma colloid osmotic pressure $\left(\pi_{\mathfrak{p}}\right)$ were produced, in rats, by feeding them diets with P:E values of 0.005 . However increases in interstitial fluid volume and oedema formation, providing evidence for excessive water filtration, were acute changes and not directly related to changes in $\pi_{p}$. It might seem then that reductions in plasma protein concentration and $\pi_{p}$ are not significant factors for oedema formation; however, other important changes occurred. As $\pi_{p}$ was reduced there were compensatory changes in interstitial fluid colloid osmotic pressure $\left(\pi_{i}\right)$ and interstitial fluid hydrostatic pressure $\left(P_{i}\right)$ and values for the sum of forces opposing filtration $\left(\pi_{p}-\pi_{i}+P_{i}\right)$ were relatively stable.

The most important contribution to the stability was made by alterations in $\pi_{i}$ which were quantitatively similar to changes in $\pi_{p}$, when $\pi_{p}$ fell; so that since $\pi_{p}: \pi_{i}$ in normal animals was approximately 2 the decreases in $\pi_{i}$ were proportionally greater than those in $\pi_{p}$. Although this compensatory mechanism is highly effective it is self-evident that it cannot be a complete protection against excessive water filtration since with increasingly low values of $\pi_{i}$ full compensation for any change that could otherwise promote increased water filtration becomes impossible unless oedema formation occurs. This event will by itself ultimately result in an increased interstitial fluid hydrostatic pressure and a return to a normal balance of transcapillary pressures.

One important consequence of the physiological adaptions described is that it is possible to understand oedema formation in malnutrition in terms of a threshold value for plasma colloid osmotic pressure. The precise value of such a threshold might vary slightly; clearly there will be considerable dependence on capillary pressure, which could not be measured in the present experiments, but the circumstances for oedema formation in the development of malnutrition or its disappearance in recovery are likely to exist over only a small range of values for $\pi_{p}$. While this view is entirely compatible with clinical experience in kwashiorkor it does not reduce the significance of alterations in the renal handling of $\mathrm{Na}$. If both homoeostatic systems and renal function are normal loss of fluid from the plasma will trigger mechanisms for the retention of $\mathrm{Na}$ and water, which would further expand interstitial fluid volume when control over the distribution of extracellular fluid is lost. Alternatively, if retention of $\mathrm{Na}$ occurs as an abnormality in the development of malnutrition (Golden et al. 1975) this would only serve to aggravate the situation when plasma protein concentrations are also reduced.

The early changes in $\pi_{p}$ and $\pi_{i}$ that occurred in the protein-deficient rats were not associated with alterations in plasma or interstitial fluid volume and, in so far as total active oncotic mass is related to total albumin mass (albumin normally provides most of the oncotic activity of plasma), this result confirms the many previous observations that reductions in extravascular albumin mass are proportionally greater than reductions in intravascular albumin mass (reviewed by Coward \& Sawyer, 1977) and explains their clinical significance.

\section{Explanations for changes in $\pi_{1}$ and $\mathrm{P}_{1}$ in protein-deficiency}

In terms of the extent of compensation provided against the reductions in $\pi_{p}$ in protein deficiency, the increases in $P_{i}$ were much less important than the decreases in $\pi_{i}$ but the 
changes in $P_{i}$ may indicate one mechanism that would allow substantial reductions in $\pi_{i}$ to occur. Under normal conditions there is a slight, continual fluid loss from plasma into the interstitium. The rate of loss is the net capillary filtration rate and the lost fluid returns to the circulation through the lymph vessels and, in a steady-state, lymph flow-rate is equivalent to capillary filtration rate; provided that lymph flow rate increases when net capillary filtration increases interstitial fluid volume will not change. $P_{1}$ is negative, i.e. subatmospheric, under normal conditions in most tissues (Guyton, 1963; Guyton et al. 197I; Scholander et al. 1968; Snashall et al. 1971; Fadnes, 1975) but the normal compliance of the interstitial space is low (Guyton, 1965,1972 ). When capillary filtration increases, $P_{i}$ also increases with only small changes in interstitial fluid volume and lymph flow rate matches net capillary filtration rate. These relationships hold until $\boldsymbol{P}_{\boldsymbol{i}}$ is near atmospheric pressure when lymph flow rate is maximal and the compliance of the interstitial space increases enormously. At this stage interstitial fluid volume increases with further increases in capillary filtration and oedema formation will occur. It is therefore reasonable to suggest that, in the present series of experiments lymph flow-rates increased when $\pi_{p}$ fell in the protein-deficient rats, and were maximal when oedema formation occurred since $P_{i}$ gradually increased to values close to zero.

Analyses of the relationships between lymph flow-rate and interstitial fluid and plasma protein concentrations (Renkin, 1964; Schultze \& Heremans, 1966 b; Reeve \& Chen, 1970; Taylor et al. I973) show that with increased rates of lymph flow, the plasma:interstitial fluid protein concentration ratio increases. This occurs because diffusion contributes substantially to the outward transcapillary movement of protein but protein transport back to the circulation is in the bulk flow of filtered fluid; in effect increased rates of lymph flow 'wash' protein out of the interstitial space and when the plasma:interstitial fluid protein concentration ratio increases $\pi_{p}: \pi_{i}$ will also increase.

It seems then, that in nutritionally-induced hypoproteinaemia, the protection against oedema formation conferred by compensatory changes in $\pi_{i}$ is simply part of a homoeostatic mechanism intended to maintain a constant distribution of extracellular fluid between the vascular and interstitial compartments. There is however an alternative explanation.

An assumption implicit in the discussion has been that in protein deficiency there is no change in capillary permeability to plasma protein but Wraight (1974) has shown that the transcapillary escape rate for albumin is decreased in rats rendered hypoproteinaemic after plasmapheresis; if this change also occurred in the present experiments it would be possible to explain the maintenance of normal pressure gradients across the capillaries when $\pi_{p}$ falls.

Each of these explanations for the manner in which oedema formation is prevented in hypoproteinaemia may be relevant in malnourished children. There is some evidence that the transcapillary escape rate for albumin determines the rate of albumin catabolism (Rossing et al. 1976) and it is well known that rates of albumin catabolism are reduced in protein-energy malnutrition (Hoffenberg et al. 1962; Cohen \& Hansen, 1962; Picou \& Waterlow, 1962; Hoffenberg et al. 1966; James \& Hay, 1968). On the other hand, although there have been no investigations on the rates of lymph flow in protein-energy malnutrition, McMaster (1937) and Langgård (I963) have shown that lymph flow-rates are increased in nephrosis. In a comprehensive review of the evidence Rusznýak et al. (I967) considered that in oedema resulting from hypoproteinaemia lymph flow-rates were maximal having gradually increased before the appearance of oedema.

\section{Relevance of rat models of oedematous malnutrition to kwashiorkor}

In the present experiments hypoproteinaemia leading to oedema was induced in rats simply by feeding them diets low in protein. The human situation is more complicated in that other 
factors are invariably involved and the extent to which protein deficiency by itself contributes to kwashiorkor is still controversial. However, irrespective of the mechanisms involved, hypoproteinaemia is a consistent finding in kwashiorkor and the relevance of these studies is that the experimental animals were also hypoproteinaemic. The hypoproteinaemia only became severe when plasma volume expanded as a result of reductions in total erythrocyte volume but anaemia is almost universal in human protein-energy malnutrition (Alleyne et al. 1977) and if food supply had been normal increased rates of plasma protein synthesis would presumably have supported a normal protein concentration in an expanded plasma volume. In conclusion, therefore, it may be suggested that the present experiments illustrate the importance of low plasma protein concentrations and reduced plasma oncotic pressures in oedematous malnutrition but it has to be accepted that in kwashiorkor, a disease with a complex aetiology, other factors may also be involved.

M.F. acknowledges receipt of a Wellcome Research Training Scholarship. The authors would also like to thank Professor M. A. Floyer for advice on the measurement of interstitial fluid pressure, Mr G. Morris for his help in making the capsules, and Miss M. Howlett and Mr L. A. R. Luff for other skilled technical assistance.

\section{REFERENCES}

Alleyne, G. A. O., Hay, R. W., Picou, D. I., Stanfield, J. P. \& Whitehead, R. G. (1977). Protein-energy Malnutrition, p. 118 . London: Edward Arnold (Publishers) Ltd.

Bratteby, L. (1967). Acta Soc. Med. Upsal. 72, 249.

Cohen, S. \& Hansen, J. D. L. (1962). Clin. Sci. 23, 351.

Coward, W. A. (1975). Br. J. Nutr. 34, 459.

Coward, W. A. \& Sawyer, M. B. (1977). Br. J. Nutr. 37, 127.

Coward, W. A., Whitehead, R. G. \& Lunn, P. G. (1977). Br. J. Nutr. 38, i 15.

Fadnes, H. O. (1975). Scand. J. clin. Lab. Invest. 35, 44I.

Golden, M. H. N., Patrick, J., Jackson, A. A. \& Picou, D. I. (1975). Lancet ii, 1044.

Guyton, A. C. (1963). Circulation Res. 12, 399.

Guyton, A. C. (1965). Circulation Res. 16, 452.

Guyton, A. C. (1972). Pflügers Archs 336, SI.

Guyton, A. C., Granger, H. J. \& Taylor, A. E. (197I). Physiol. Rev. 51, 527.

Hoffenberg, R., Black, E. \& Brock, J. F. (1966). J. clin. Invest. 45, I43.

Hoffenberg, R., Saunders, S., Linder, G. C., Black, E. \& Brock, J. F. (1962). In Protein Metabolism, p. 314 [F. Gross, editor]. Berlin: Springer-Verlag.

James, W. P. T. \& Hay, A. M. (1968). J. clin. Invest. 47, 1968.

Jelliffe, D. B., Bras, G. \& Stuart, K. L. (1954). W. Indian med. J. 3, 43.

Katz, J., Bonorris, G., Golden, S. \& Sellers, A. L. (1970). Clin. Sci. 39, 705.

Klahr, S. \& Alleyne, G. A. O. (1973). Kidney int. 3, 129.

Lancet (1970). Lancet ii, 302.

Langgård, H. (1963). Acta med. scand. r74, 645.

McMaster, P. D. (1937). J. exp. Med. 65, 373.

Montgomery, R. D. (1963). Archs Dis. Childh. 38, 343.

Picou, D. I. \& Waterlow, J. C. (1962). Clin. Sci. 22, 459.

Reeve, E. B. \& Chen, A. Y. (I970). In Plasma Protein Metabolism, p. 89 [M. A. Rothschild and T. Waldman, editors]. New York and London: Academic Press.

Renkin, E. M. (1964). The Physiologist 7, 13.

Rossing, N., Parving, H-H., \& Lassen, N. A. (1976). In Plasma Protein Turnover, p. 357 [R. Bianchi, G. Mariani and A.S. McFarlane, editors]. London: The Macmillan Press Ltd.

Rusznýak, I., Földi, M. \& Szabó, G. (1967). In Lymphatics and Lymph Circulation, 2nd English ed., p. 277 [L. Youlten, editor]. Oxford: Pergamon Press.

Scholander, P. F., Hargens, A. R. \& Miller, S. L. (1968). Science, N.Y. 161, 32 I.

Schultze, H. E. \& Heremans, J. F. (1966a). Molecular Biology of Human Proteins, vol, I, p. 602. Amsterdam, London and New York: Elsevier.

Schultze, H. E. \& Heremans, J. F. (1966b). Molecular Biology of Human Proteins, vol, 1, p. 625. Amsterdam, London and New York: Elsevier.

Snashall, P. D., Lucas, J., Guz, A. \& Floyer, M. A. (197I). Clin. Sci. 4I, 35. 
Srikantia, S. G. (1968). In Calorie Deficiencies and Protein Deficiencies, p. 203 [R. A. McCance and E. M. Widdowson, editors]. London: J. \& A. Churchill.

Starling, E. H. (1896). J. Physiol., Lond. 19, 3 I 2.

Taylor, A. E., Gibson, W. H., Granger, H. J. \& Guyton, A. C. (1973). Lymphology 6, 192.

Trowell, H. C., Davies, J. N. P. \& Dean, R. F. A. (1954a). Kwashiorkor, p. 22. London: Edward Arnold (Publishers) Ltd.

Trowell, H. C., Davies, J. N. P. \& Dean, R. F. A. (1954b). Kwashiorkor, p. 218. London: Edward Arnold (Publishers) Ltd.

Viart, P. (1977). Am. J. clin. Nutr. 30, 349.

Waterlow, J. C. \& Alleyne, G. A. O. (1971). Adv. Prot. Chem. 25, 117.

Waterlow, J. C., Cravioto, J. \& Stephen, J. M. L. (1960). Adv. Prot. Chem. 15, 131.

Wraight, E. P. (1974). J. Physiol, Lond. 237, 39. 